\title{
THE LARVAL STAGES OF PORTUMNUS (CRUSTACEA BRACHYURA) WITH NOTES ON SOME OTHER GENERA
}

\author{
By Marie V. Lebour, D.Sc. \\ Naturalist at the Plymouth Laboratory
}

(Text-figs. I-5)

Two species of Portumnus occur in the Plymouth area, P. biguttatus (Risso) and $P$. latipes (Pennant). P. biguttatus was the only species recorded when the old fauna list of Plymouth was published (1904), but since then it is known that $P$. latipes is very common in certain sandy areas (see Plymouth Marine Fauna, 193I), far commoner than P. biguttatus.

P. biguttatus is rare and has not been seen since 1906. It was first found by W. Garstang and R. Todd on Drake's Island in Plymouth Sound, burrowing in fine gravel (1905), and two specimens, $o^{\hat{t}}$ and $\rho$, are recorded from a sandy patch from the north-east corner of Drake's Island. A female in berry was recorded from the same locality by R. Todd, and L. R. Crawshay dredged one in Cawsand Bay in 1906. Apparently the eggs were not hatched out and the zoea of this species is unknown. In August 1902 R. Gurney obtained a megalopa in the plankton and from it secured the first crab stage. He describes the megalopa as being intensely blue. The cast skin of the megalopa and the crab obtained from it (Fig. $3 a-c$ ), which he kindly handed to me, are described in my paper of 1928 (Lebour, I928c, p. 518, pl. viii, figs. I-3). There is no reason to doubt the accuracy of the determination, especially because, as shown below, corresponding stages of $P$. latipes as well as the zoeae are now known and are very distinct, differing considerably from those of $P$. biguttatus.

Portumnus latipes occurs commonly at low water and below, burrowing in sandy beaches on the Cornish coast. It is found in abundance in Whitsand Bay, but the berried female has only lately been captured and the eggs hatched out. The crabs live at a depth of about four to six inches when the sand is uncovered by the tide; but they probably swim about just above the surface or are covered lightly by the sand when the tide is up, for they can be caught by skimming a shrimping net along the sand in the water. Very small crabs can be obtained in this way, probably only a few stages from the megalopa.

In 1928 an unidentified zoea from the plankton was provisionally attributed to Pirimela denticulata? (Lebour, I928c, pp. 518-2I, pl. i, fig. 9; pl. vii, fig. 6; pl. viii, figs. 4-6). I have since hatched out the larva of Pirimela which agrees in essentials with the descriptions by Kinahan (I857 $b, \mathrm{I} 862$ ) and Cano (I892a). The discovery that this unidentified zoea is really that of Portumnus latipes 
is due to Mr F. Hinrichs of the Staatliche Biologische Anstalt in Heligoland, who, in I935, wrote to inform me that some years previously (I9II, I9I2) he had hatched out the larvae of this species, procured all the zoeal stages from the plankton, and also studied the megalopa and young stages, and that these agreed with my description of the queried Pirimela. Since he has not published anything on the subject and it is important that the life histories of these crabs should be correctly known, it now seems a suitable opportunity to put them on record and correct the previous erroneous supposition.

Portumnus latipes in berry was obtained on 20 June 1940, from Whitsand Bay. It was dug out of the sand with a fork at low spring tide just above low water, about four inches down. These crabs are frequently found in similar situations by the fishermen digging for sand-eels (Ammodytes) which they use for baiting their long lines set on the beach. They informed me that they always kill the crabs as they eat the bait. Besides sand-eels, nereids and amphipods are commonly dug up in the same habitat. When kept in captivity the adult crabs ate pieces of mussel and Nereis. When placed in sand they dig themselves in with all the walking legs, but when disturbed they can swim easily. When dug up on the beach they burrow deeply as they are uncovered, but they also escape by running quickly along the sandy beach.

The female, in good condition, carried a large mass of eggs, greenish brown due to black chromatophores and yellowish yolk. The eggs were nearly ready to hatch with a small amount of yolk. The chromatophores were bordered with yellow. The berried female was placed in a plunger jar and the eggs hatched on 23 June. The eggs measured $0.32 \mathrm{~mm}$. across (Fig. I $a$ ) and the pre-zoea obtained from them measured $\mathrm{I} \cdot \mathrm{I} 2 \mathrm{~mm}$. in length without the long spines (Fig. I $b$ ). The pre-zoeal skin was so extremely thin that it was impossible to make out the details of the spines. There are four zoeal stages as in Carcinus maenas, and the zoea resembles that species in many ways, especially in the arrangement of chromatophores and in having no lateral spines on the carapace. The body is clear and transparent but there are numerous nearly black chromatophores edged with yellow and there is a pinkish tinge all round. A very conspicuous series of dark chromatophores extends laterally along the body as in Carcinus. The rostral and dorsal spines are, however, considerably longer. There are chromatophores on the dorsal spine, in front of the eyes, on the thorax, mandible and first and second maxillipedes, on each abdominal somite ventro-laterally and on the telson. The last (fourth) zoea has already been described as Pirimela (?) (Lebour, I928c, p. 520, pl. i, fig. 9), and the megalopa and two crab stages reared from it (p. 520, pl. vii, fig. 6; pl. viii, figs. 4,5 ). As very young crabs, about stages four and five after the megalopa, were caught in June, and as these almost certainly must be from spring larvae, it follows that the breeding season must be a fairly long one, extending from spring to autumn, for the last zoeae and megalopae were found in the plankton from July to October. The usual breeding season, however, appears to be in the summer months. 
The first zoea (Fig. I $c, e$ ) measured $\mathrm{I} \cdot 6 \mathrm{~mm}$. from the tip of the dorsal spine to the tip of the rostral spine, the length of the body being $c a$. I $3 \mathrm{~mm}$. Both spines are slightly curved. There are no lateral carapace spines. The antennules and antennae are like those of all Portunids. The antennal exopodite is about half the length of the spinous process, with one long and one very short spine at the tip. The second abdominal somite has a lateral hook each side,

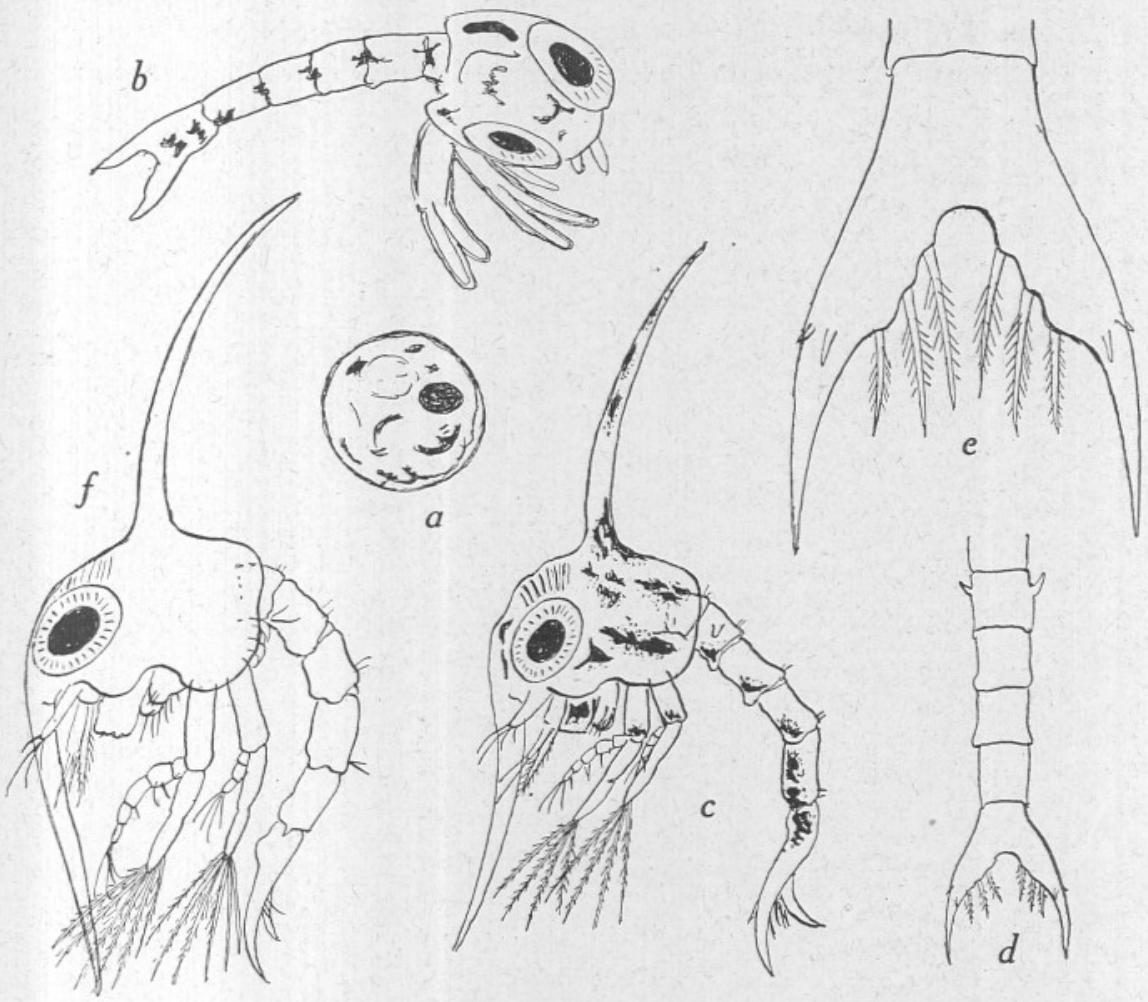

Fig. I. Portumnus latipes. $a$, egg, $0.32 \mathrm{~mm}$. across; $b$, pre-zoea from egg, $\mathrm{I} \cdot \mathrm{I} 2 \mathrm{~mm}$. long $c$, first zoea from pre-zoea, $\mathrm{I} \cdot 28 \mathrm{~mm}$. from spine to spine; $d$, abdomen and telson of same; $e$, telson of same; $f$, second zoea from first from pre-zoea, $\mathrm{I} \cdot 8 \mathrm{~mm}$. from spine to spine.

but there are no lateral spines on any of the somites. The telson has two lateral spines instead of the usual three of the Portunid, the outer spine being very small and disappearing in the later stages, leaving only one as in Carcinus. Hinrichs obtained second, third and fourth zoeae from the plankton in Heligoland. The first zoea was hatched from the egg in a plunger jar; the second zoea moulted from the first in a bowl; the fourth (and last) zoea was obtained in the plankton.

The second zoea (Fig. If) measured $\mathrm{I} \cdot 8 \mathrm{~mm}$. from spine to spine, the length of the body being $c a .1 \cdot 6 \mathrm{~mm}$. In essentials it is like the first, but there are 
six setae on the ends of the maxillipedes and only one lateral spine on each side of the telson. The third zoea was not seen, but Hinrichs found it in the plankton in Heligoland.

The fourth zoea (last) (Fig. 2) was obtained several times from the Plymouth plankton. The length from spine to spine was $3.6 \mathrm{~mm}$., the body length $3.2 \mathrm{~mm}$. There were ten setae on the maxillipedes and the pleopods were long and without setae. It is much more elongated than the corresponding stage of Carcinus and is not so darkly coloured, dark chromatophores being mixed with yellow and pinkish red. The last zoea moulted in the laboratory to the megalopa.

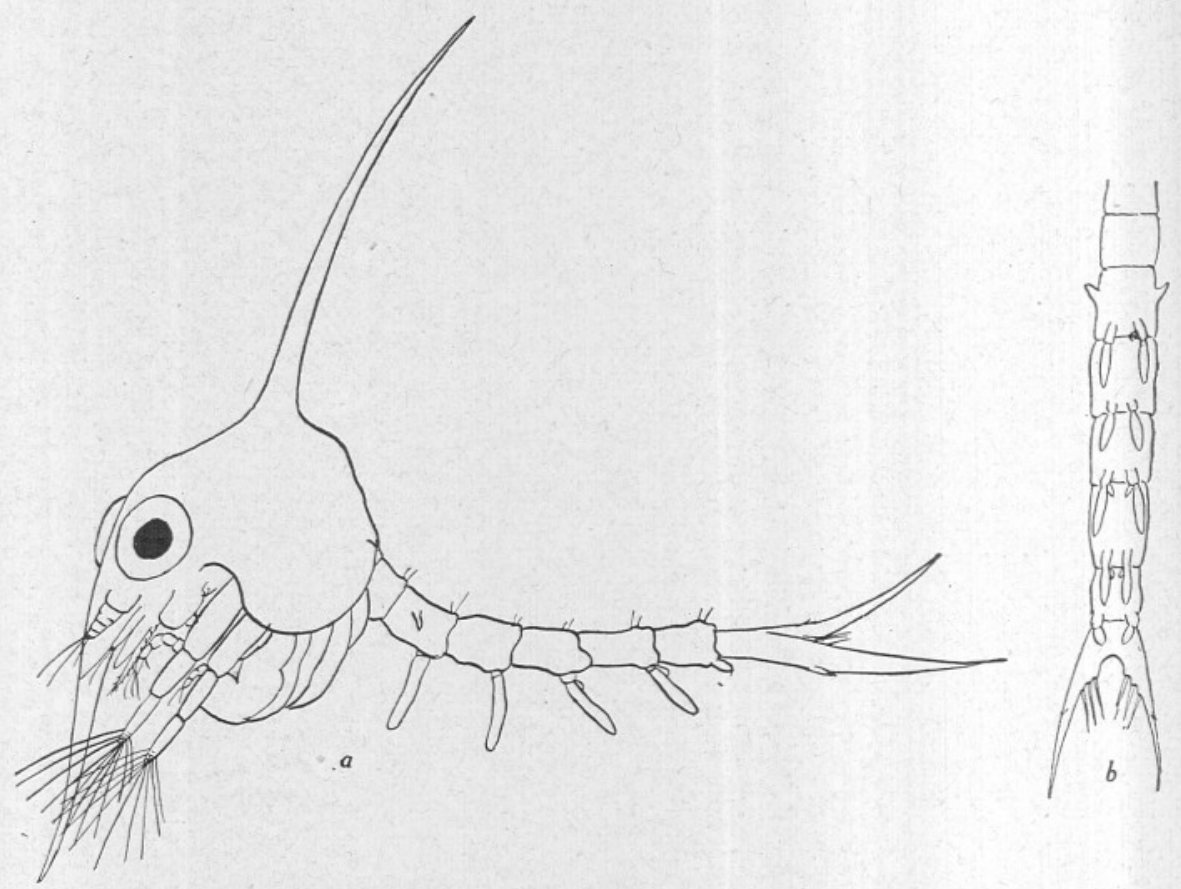

Fig. 2. Portumnus latipes. a, fourth (last) zoea from plankton, $3.6 \mathrm{~mm}$. from spine to spine; $b$, abdomen of cast fourth stage.

The megalopa (Fig. $3 d$ ) measured $2 \mathrm{~mm}$. from the tip of the rostral spine to the end of the carapace. Unlike any known Portunid it has a dorsal spine and thus resembles Cancer and Atelecyclus. It is coloured in much the same way as the last zoea and has long dark chromatophores on each side of the carapace in the same position as in Carcinus. The rostrum is pointed and sticks out horizontally, the dorsal spine being curved. The carapace is broad with inconspicuous protuberances. There are seven setae on the last pleopods. There is a large hook on the ischium of the first leg, but no hooks on the other legs. The presence of the dorsal spine and the absence of hooks on the legs 


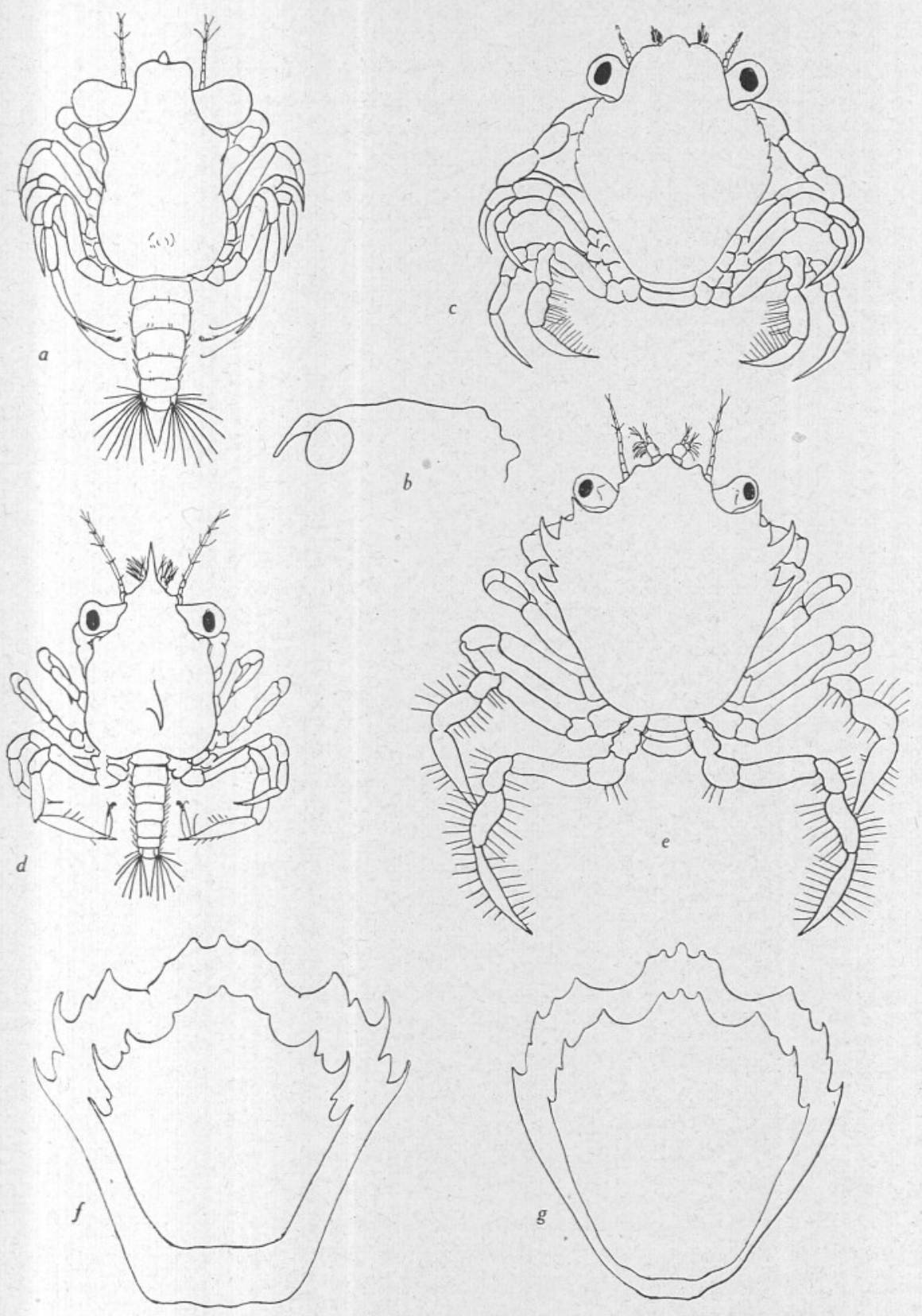

Fig. 3. Portumnus latipes and P. biguttatus. $a-c, P$. biguttatus: $a$, megalopa, cast skin, carapace $2.2 \mathrm{~mm}$. long; $b$, carapace of same, side view; $c$, first young crab stage from megalopa, length of carapace $2 \cdot 3 \mathrm{~mm} ; d-g, P$. latipes: $d$, megalopa from last zoea, carapace $2 \mathrm{~mm}$. long; $e$, first young crab from same, carapace $2.4 \mathrm{~mm}$. long; $f$, carapace of first and second crab stages (first from megalopa, carapace $2.4 \mathrm{~mm}$. long, second from first, carapace $3.52 \mathrm{~mm}$. long); $g$, carapace of $c a$. fifth and $c a$. sixth young crab stages consecutive moults), 8.5 and $10 \mathrm{~mm}$. across greatest width. 
other than the first (usually present in the Portunidae) are characters which set this megalopa apart from all the other British Portunidae. The megalopa moulted to the first crab stage.

The first crab stage (Fig. $3 e, f$ ) obtained from the megalopa is striking in having the last pair of legs with paddles bearing swimming setae on both sides, like Portunus, whereas the adult Portumnus bears these on one side only except for a small row at the proximal end of the outer side. This last character of the first crab stage was regarded in the previous paper as an indication that it

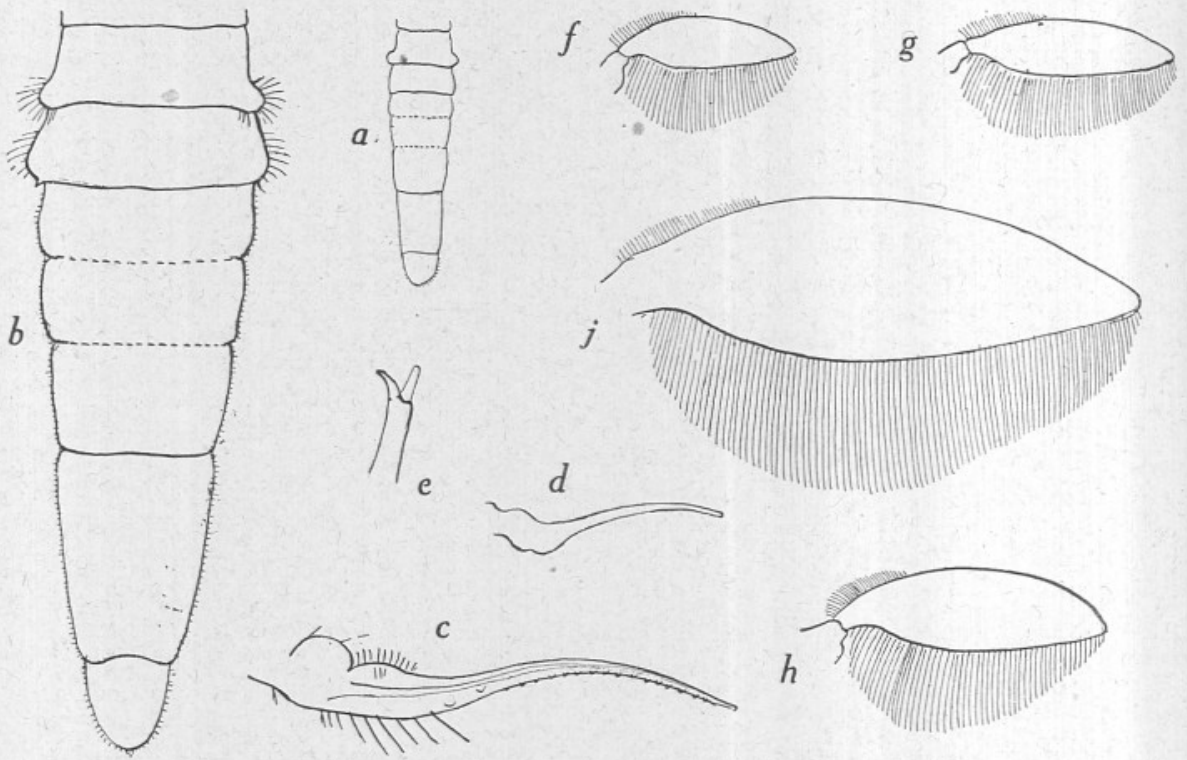

Fig. 4. Portumnus latipes. $a$, abdomen of cast, ca. fifth crab stage; $b$, abdomen of adult $\hat{o}$; $c$, first pleopod of $c a$. fifth crab stage, $\delta ; d$, second pleopod of same; $e$, tip of second pleopod of adult $\delta ;$, paddle of last leg of $c a$. fifth crab stage; $g$, paddle of the next stage (moulted); $h$, paddle of the next stage (moulted); $j$, paddle of adult.

did not belong to Portumnus (Lebour, 1928, p. 42I). A study of a series of stages, however, shows that the setae on one side dwindle and finally almost disappear (Fig. $4 f-j$ ).

The first crab stage obtained from the megalopa of P. biguttatus (Fig. $3 \mathrm{c}$ ) has no hairs on one side of the paddle and it seems that we probably have a series in the Portunidae from Portunus through Portumnus latipes and P. biguttatus to Carcinus which has no swimming paddles. Unfortunately the megalopa of Portumnus biguttatus was not noticed in detail before moulting, and it is impossible to be sure whether a dorsal spine was present on the carapace or not. There is an indication near the centre that a prominence, now more or less collapsed, was present and may have been a spine (Fig. $3 a, b$ ). The first 
young stage is very different in the two species, and the differences in both megalopa and crab, as well as in the adult, may warrant a separation into different genera. In the early crab stages of $P$. latipes the shape of the carapace is different from that of the adult, being broader in proportion to the length, and the lateral teeth are much more pointed and hook-like. Young stages, probably about the fifth, are much more like the adult (Fig. $3 f, g$ ). The abdomen of a male in this stage is like the adult (Fig. $4 a, b$ ), having segments 3-5 fused with only an indication of a suture between 3 and 4 , and 4 and 5 . The male pleopods of $P$. latipes are interesting, for in the adult the second pleopod is bifurcate whilst in Carcinus it is simple (although similar in other respects) (Fig. $4 c-e$ ). In the early stages up to about stage 5 there is no bifurcation. The affinity with Carcinus is apparent in many ways throughout the life history.

Some notes on the feeding of the young Portumnus latipes may be given. A last zoea was obtained in the inshore plankton on 9 September 1943, which moulted during the night to the megalopa. It was kept in a glass finger bowl until it moulted to the first crab stage on 23 September, and lived until 3 October when it died without further moult. During this time the water was frequently changed and a variety of food offered. All the Plymouth crabs previously reared readily ate pieces of mussel, Mytilus edulis, and both megalopa and crabs moulted, but this megalopa, although it occasionally ate mussel, did not like it and it was obviously not a congenial food. Various other invertebrates were tried, many of which were eaten. The following is a list:

9. 9. 43. Newly moulted megalopa ate many dead, but newly killed, Oikopleura.

I0. 9. 43. The megalopa ate a moribund Calanus, Pseudocalanus and Upogebia larva, picking out the flesh and rejecting most of the cuticle of the copepods but eating practically the whole of the Upogebia. The food was held in the chelae and eaten either when swimming or when resting on the bottom of the bowl.

I3. 9. 43. The megalopa ate a moribund Upogebia larva.

I6. 9. 43. The megalopa ate a piece of the mantle of a Teredo. It was noticed that the large hook on the ischium of the first leg helps in holding the food fast while the crab swims. It also ate a moribund Processa larva.

23. 9. 43. The megalopa moulted to the first young crab which ate two dead Autolytus sp., but did not eat pieces of mussel (foot and mantle). which were present. In a few days, however, it ate some of the mussel. The crab always dances round the food as though testing and smelling it before grasping it.

24. 9. 43. The young crab ate muscles of a newly killed Crangon vulgaris, preferring it to mussel.

28. 9. 43. The young crab ate muscles of Crangon, a young cockle taken from its shell, and a moribund Macropodia zoea. The crab was at first almost colourless, but now has a brownish yellow colour.

29. 9. 43. The young crab ate a moribund pagurid larva and a moribund Macropodia larva. The cuticle of both was rejected.

30. 9. 43. The young crab ate a young cockle removed from its shell.

From these observations it appears that the natural food of the megalopa and young crab is small crustacea, mollusca and worms, but that it probably 
does not catch them alive for in no case when live material was offered was it eaten. Worms, molluscs and copepods could easily be obtained, whilst the megalopa would probably catch the dead plankton. It has already been shown that the adult eats dead fish and worms.

\section{The Zoea of Pirimela denticulata Montagu}

A female in berry from Wembury was kept in a plunger jar and the eggs hatched out. The eggs when ready to hatch measured $0.4 \mathrm{~mm}$. across. The pre-zoea obtained from the egg (Fig. $5 a$ ) is very like Portunus, but it was
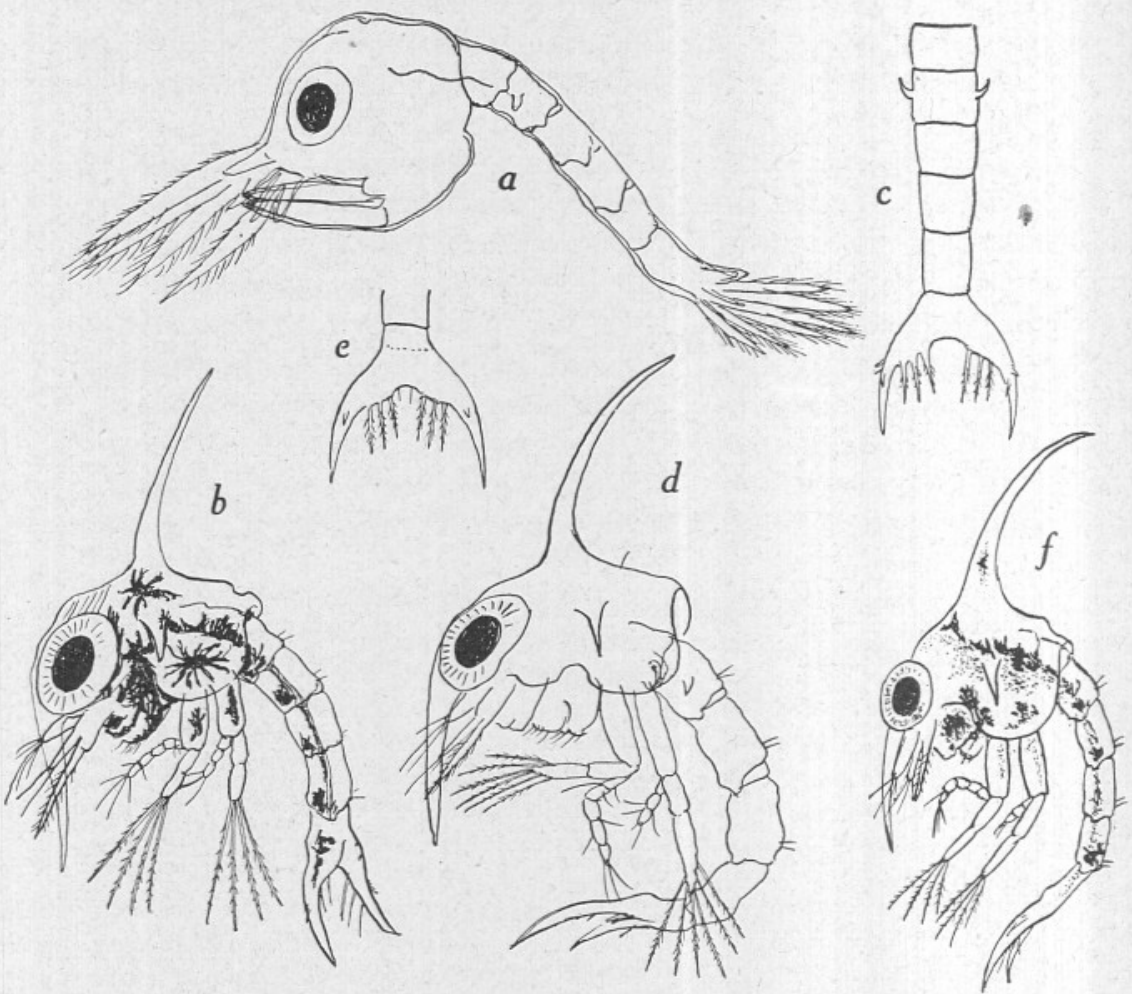

Fig. 5. Pirimela denticulata and Polybius henslowi. a-e, Pirimela denticulata: $a$, pre-zoea from egg, $\mathrm{I} \cdot 8 \mathrm{~mm}$. long; $b$, first zoea from pre-zoea, $\mathrm{I} \cdot 3 \mathrm{~mm}$. from spine to spine; $c$, abdomen and telson of same; $d$, second zoea from first, $\mathrm{I} \cdot 3 \mathrm{~mm}$. from spine to spine; $e$, telson of same; $f$, Polybius henslowi, first zoea from pre-zoea, I.4 mm. long.

unfortunately impossible to ascertain whether there were three or four large spines on the antennal exopodite, the number distinguishing Portunus and Cancer.

The first zoea (Fig. $5 b, c$ ) from the pre-zoea is pale greenish with thick very dark brown chromatophores along the thorax and abdomen, on the carapace, in the mouth region and on the bases of the maxillipedes. The zoea, 
which agrees with the description by Kinahan (1856-59) who hatched out the species, is like Portunus, with lateral spines on the carapace and three external spines on the telson. A pair of lateral hooks is present on the second abdominal somite. The first zoea measured $\mathrm{I} \cdot 4 \mathrm{~mm}$. in length and $\mathrm{I} \cdot 34 \mathrm{~mm}$. from spine to spine. This moulted to the second zoea.

The second zoea (Fig. $5 d-e$ ), from the first, measured $2 \mathrm{~mm}$. long and $\mathrm{I} \cdot 3 \mathrm{~mm}$. from spine to spine. Thus whilst the body is larger the spine measurement is the same as that of the first zoea. The colouring is the same. There are six setae at the tips of the exopodites of the maxillipedes and faint rudiments of the third maxillipede and legs. There is only one lateral spine remaining on the telson, but there is an extra pair inside the fork. There is a faint line showing beneath the cuticle where the division of the fifth and sixth abdominal somites occurs.

No further stages were obtained, therefore it is not known how many zoeal stages there are. Cano (I89I) figures the megalopa, which has a pointed rostrum and no dorsal spine, the first leg having a large hook on the ischium. $\mathrm{He}$ also figures a second megalopa stage and a first young crab stage which he attributes to Pirimela. None of the British crabs has two megalopa stages, indeed it is very unusual for there to be two (see Gurney, 1942, p. 37). It is possible that Cano may have had an older megalopa really in the first and only stage. As his specimens were taken in the plankton we cannot be sure that they belong to Pirimela. As far as we know from its larval stages Pirimela is probably related to Portunus and Cancer, perhaps more nearly to Cancer.

\section{POLYBIUS HENSLOWI LEACH}

Polybius henslowi Leach (Fig. $5 f$ ) is rare in the Plymouth area, being occasionally taken in the deeper waters. The first zoea has already been described from specimens obtained by Todd and hatched by him from the egg (Lebour, I928c, p. 516, pl. iv, fig. 6). A female in berry was obtained from outside waters (I7. I2. 3I) and the eggs hatched out in a plunger jar. This is the first time that colour notes are available. The eggs ready to hatch measured $0.36 \mathrm{~mm}$. across. The pre-zoea from the egg measured $\mathrm{I} \cdot \mathrm{I} 2 \mathrm{~mm}$. in length with conspicuous orange and black chromatophores. The pre-zoeal skin was too fragile for complete examination of the spines. The first zoea from the pre-zoea is transparent with a slight yellowish green tinge and dark brown chromatophores accompanied by yellow and orange on the dorsal spine about one-third of the way up, on the eye (yellow and orange), carapace, abdomen and mouthparts (dark brown, orange and yellow), the dark chromatophores forming a line along each side of the carapace and along almost the whole length of the abdomen. No further stages were available.

All literature is to be found in R. Gurney's Bibliography of the Larvae of Decapod Crustacea, Ray Society, 1939 and Larvae of Decapod Crustacea, Ray Society, 1942. 